\title{
Effect of Corporate Governance Attributes on Environmental Disclosure of Listed Manufacturing Companies in Nigeria
}

\author{
Ahmed A. Abubakar PhD, FCA. \\ Department of Accounting Adamawa State University, Mubi. \\ Simon Moses \\ Department of Accounting Adamawa State University, Mubi.
}

\begin{abstract}
This research examined the effect of corporate governance attributes on environmental disclosure of listed manufacturing companies in Nigeria. The data for the study were collected from annual reports and accounts of the sample twenty (20) companies listed on the Nigerian Stock exchange for the period of seven years from 2012 to 2018. Empirical analyses were carried out using correlation matrix, regression analysis. Regression analysis was used in testing hypothesis using Stata 11.0. The result of fixed effect rgression reveals independent directors has significant positive effect on the environmental disclosure of listed manufacturing companies. While foreign directors, directors with dual membership and educational background of the directors have positive insignificant effect on environmental disclosure of listed manufacturing companies in Nigeria. The study therefore, recommends that management of company should have environmental committee to help them monitor and identify environmental need in their host communities. Government should come with policy that will make every company participate in environmental activities and monitor such.
\end{abstract}

Keywords: Environmental disclosure, independent director and foreign directors

DOI: $10.7176 / \mathrm{EJBM} / 12-27-07$

Publication date:September $30^{\text {th }} 2020$

\subsection{Introduction}

Awareness and concern about business activities that affect the environment began to emerge and increase in about four decades ago (Hartikayanti, Trisyardi \& Saptono, 2016). As the world economic development and business industries' grow, it came with negative environmental impacts such as climate change, global warming, environmental degredation and pollution (Fortunella \& Hadiprajitno, 2015). As a result of these, industries effect on the environment has led companies to incur cost toward saving the environment, Hence the need for environmental disclosure became pertinent.

Environmental disclosure therefore, is the reporting on the impacts of company activities on natural environment such as waste management, recycling, carbon management, emission control, pollution, wetland and wildlife conservation (Gatimbu \& Wabwire, 2016). Disclosing the commitment of company towards its environment is important, because environment is seen as important resources to every company. As shareholders are not only interested in company's income statement but also concerned about company's performance on social, environmental and human capital resources issues (Uddin \& Safiddin, 2015). Therefore companies' inorder to meet shareholders expectations should include in its annual reports environmental information. Through environmental information disclosure, company will gain stakeholders confidence in its company, where Akanno, Che, Radda and Uzodinma (2015) posited that environmental impact disclosure is an important part of the company strategy to communicate to the stakeholders and it add value to corporate accounting reports. Through environmental impact disclosure, companies can enjoy the benefit of lower cost of capital because of the goodwill created by environmental information disclosure. The disclosure of this environmental information can be influence by firm's attributes and corporate governance.

Corporate Governance is a detailed system by which firms are controlled, in a way lead to accomplishing firms' and their stakeholders. Such system influences all procedures conducted within firms and as a result, it is reasonable to expect that such system is also affecting the communication process between firm and all interested groups in society.

Research publication in this topic still focus much on the western society. Among the studies that examined this topic, much have centered on other companies other than manufacturing companies. Therefore, this research is out to add to the growing body of knowledge in the environmental disclosure using manufacturing companies listed on the Nigerian Stock Exchange to empirically examine the influence of corporate governance on environmental disclosure.

\subsection{Literature Review}

2.1 Concept of Corporate Governance

Cadbury Committee (1992) clearly defined corporate governance as the system by which companies are directed 
and controlled. Aburaya (2012) noted that corporate governance is concerned with internal aspect of company, such as internal control and board structure, and external aspect such as relationship with shareholders and other stakeholders. Farinba (2013) started that corporate governance is the precise way in which monitoring devices are set up and fulfil their role in a particular organisation. Elsakit and Worthington (2014) asserted that corporate governance is a detailed system by which firm are control, in a way that leads to accomplishing firm and their stakeholders' goal. The existence of corporate governance is to protect the interest of stakeholders. As posited by the defination above the system is the combination of mechanisms which ensures that the management i.e. the agent runs the firm for the benefit of one or several stakeholders the pricipals.

\subsection{Concept of Environmental Disclosure}

Soliman (2013) viewed environmental disclosure as a disclosure of additional information in addition to mandatory informations. Every company published its financial statement yearly which shows the performance of a company. They are some information that companies must disclosed on their financial statements such as income statement, statement of financial position, accounting policies and others as requiered by general accepted accounting principle (GAAP). In order to make the financial statement look more roburst in the sight of stakeholders, it is pertinent to disclose the performance of company about its host environment. That is the effect of company's activities on the environment, how do the company intend to remedy such effects, how do they wish to bring development to the community. As conceived by the above author, attaching the aforementioned data to annual reports, portray that a company is voluntarily disclosing information about social and environment. However, environmental disclosure in some countries is been made mandtory while some countries environmental disclosure is optional but it however help in greening corporate report.

Setyawan and Kamilla (2015) defined environmental disclosure as a disclosure made by the company to the stakeholders in form of reports on environmental acvtivities undertaken by the company. A company that seeks continuinity into perpetuity and good performance must consider its stakeholder by being legitimate company. This can be achieved through proper care and disclosure of that environmental information to the stakeholders.

Environmental disclosure is the strategic way taken by the management of an organization inorder to capture community perception towards their operations by making environmental data available on company's annual report. It is strategic because environmental disclosure in must countries is on voluntary basis, it is the decision of a company to disclose information that relate to environment. Any company that seeks to achieve good performance and sustainability should not ignore the benefits to engage in social approach (Alkhili \& Ansi, 2012). Oba and Fodio (2012) disclosure on environmental issues can be considered as element of good corporate governance. Melina (2012) by disclosing information regarding company's environmental practices may be beneficial to a company's reputation than their actual environmentally friendly performance. Disclosure of environmental performance in an annual report is to show the level of accountability and corporate transparency to investors and other stakeholders (Setyawan \& Kamilla, 2015).

\subsection{Corporate Governance and Environmental Disclosure}

Stakeholders concern about the quality of environment has motivated companies to employ more environmental friendly activities and operations (Adinehzahdeh, Jaffar, Shukor \& Abdulrahman, 2018). As a result of this concern and presure from stakeholders have awaken corporate governance to embrance environmental disclosure in their decision making. It is believed that corporate governance influences environmental disclosure. This statement has been supported by Ajibolade and Uwuigbe (2018) that good corporate governance can be seen through environmental disclosure. Where they opposed that corporate social and environmental disclosure appear to be one of the most important news worldwide governance practices with many governance principles now recognizing the importance of addressing issues regarding the wellbeing of the society. Agency theory also started that there exist a relationship between corporate governance and environmental disclosure because they are both considered as control mechanism. Adinehzahdeh et al (2018) avered that effective board members are influential in making crucial decisions about environmental compliance and strategies and therefore improve environmental performance.

\subsection{Empirical Review}

Rabi (2018) examined board characteristics and environmental disclosure from Jordan. Data for the study were collected from annual reorts and accont of companies where multiple regression was used to analyse the data obtained. The finding that emerged from the study suggested positive significant relationship between board size and board ownership with environmental disclosure.

Trireani and Djajadierta (2016) looked at corporate governance and environmental disclosure in the Indonesian Mining industry. Data for the study were collected from annual reports and account of the sampled companies. Descriptive statistics was used to analse the data for the study. Result the study revealed that the extent of environmental disclosure made $b$ these companies was moderate, and that there is a significant positive 
relationship between size of board of directors, and the extent of environmental disclosure.

Ajibolade and Uwuigbe (2013) asssessed the effects of corporate governance on corporate social and environmental disclosure among listed firms in Nigeria. Annual reports ere used to collect data for the study. The data obtained were analysed using correlation and regression analysis. The study finding revealed a significant negative relationship between CEO dualit, and corporate social and environmental disclosure, while a significant relationship was recorded between non executive directors, board size, audit size and corporate socail and environmental disclosure.

Aburaya (2012) studied the relationship between corporate governance and environmental disclosure evidence from UK. Annual reports were used to collected data for the study. Multiple regressions were used to analyse data. The finding revealed corporate governance mechanism is significant at some categorical levels of environmental disclosure.

Emmanuel, Uwuigbe, Teddy, Tolulope and Eyotomi (2018) studied corporate diversity and corporate social and environmental disclosure of listed manufacturing companies in Nigeria. Annual reports were used to collect data for the study. Multiple linear regression were employed to analyse the data obtained where the study forwarded that board size, foreign directors and gender diversity have significant positive influence on environmental dfisclosure. On the other hand, there exist an insignificant positive influence beteen independent directors and environmental disclosure.

Akbas (2016) looed at the relationship between board characteristics and environmental disclosure of Turkish companies. Data were obtained from annual reports of companies listed on Turkish Stock Exchange. Regression analsis was perform to analyse the study data. The study suggested board size has a satistical relationship with the extent of environmental disclosure.

Masud, Nurrunnabi and Bae (2018) examined the effects of corporate governance on environmental sustainability reporting. Evidence from South Asian countries. The study considered three asian countries include Bangladash, India and Paistan. Data for the study were obtained from the annual the above three countries. Correlation matrix was used to analyse the data obtained. The finding suggested environmental social responsibility reporting has negative association with foreign ownership, board independence and board size.

Ofoegbu and Odoemelam (2018) examined corporate governance and environmental disclosure quality. The study were conducted in two countries include South Africa and Nigeria. The study data were extracted from annual reports and account of sampled companies from the two contries. Both descriptive and multivariate regression was used to comparatively analyse the data obtained. The result suggested a more significant positive association between board characteristics and environmental disclosure in South Africa and less relevance association in Nigeria. Also the result support that independence arragement may serve as bounding mechanism in weak reporting environments, suggesting a sustantive relationship between board independence and the regulatory framework.

Aliyu (2018) looked at board characteristics and environmental reporting in Nigeria. The study obtained data from annual reports of companies listed on the Nigerian Stock Exchange. Multiple regression models were used to analyse data for the study. The study revealed significant positive relationship between board independence and corporate environmental reporting. Similarly, a positive relationship between board meeting and corporate environmental reporting. However, there is no significant relationship between other hypothesis variables.

Ahmad and Nosahare (2015) examined directors' culture and environmental disclosure practices of companies in Malaysia. Data were collected from companies' annual reports and account. Multiple regressions were used to analyse the study data. The results uncovered significant relationship between environmental disclosure and board dominated by Bumipitra directors, board dominated by foreign directors.

\subsection{Theoritical Framework}

For purporse of this research three theories will be reviewed which will include; agency theory, legitimacy theory and stakeholder theory out of which the study will be underpin to one theory.

\subsubsection{Agency theory}

Agency theory was developed by Jessen and Meckling in 1976 in which they said agency theory is the theory on how the governance of the company is based on the conflict of interest between the company owners, its managers and major providers of debt financing. In line with this premise Mohamad, Olfa and Fauzi (2014) are of views that agency theory ia all about the conflict of interest between shareholders and creditors, between shareholders and managers. Where they further explained that the theory was developed on the contractual relationship between shareholders and creditors and managers. In the same vein, Crowther and Renu Jatana (n.d) emphasied agency theory that managers should act as custodians of the rganisation and its operational activities and places upon them the burdern of managing in the best interest of the owners of business. According to this theory all other stakeholders are irrelevant and if they benefit from the then this is coincidental to the activities of the activities of management in running the business to serve shareholders (Crowther and Renu Jatana, n.d). This focused on shareholders alone as the intended beneficieries of a business has been questioned cosiderably from many 
perspectives, which argued that it is either not the way in which a business actually run or that it is a view which does not meet the needs of society in General. Mohamad, Olfa and Fauzi (2014) the agency theory captures the firms as a legal entity, node a set of contract formal or informal or an agency relationship partners that composed it.

Cadbury committee (1992) stated that agency theory literature provides a fframework to study the relationship between corporate governance variables and corporate social responsibility disclosure since both can be considered as control mechanism. Emmanuel et al. (2018) avered that agency theory creates a structure that link corporate diversity to social, environmental reporting. This theory expresses the interplay of contractual agreement that exists between an agent and the owners of the investment.

Agency theory has been critized on the ground that it focused on only on principle and one agent while they are parties that could affect the success of business.

\subsection{Methodology}

This study adopts ex-post facto research design. The population of this study comprised of sixty (60) quoted companies on the NSE as at $31^{\text {st }}$ December, 2018. The choice of these manufacturing companies is because of its role in economic development and manufacturing sector is one of the vibrant sectors in the NSE. Also the activities of manufacturing company can directly affect the environment. The sample size of this study is twenty (20) manufacturing companies listed on the Nigerian stock exchange. The sample size was arrived at by using non purposes sampling method (purposive). Where the researcher set a standard that a company must posses before selection which include company must be listed on NSE during period of study, a company must have complete annual reports for the period of study (data availability). The source of data for this study is secondary sources. Annual reports and accounts of the selected companies were used to extract data on firm characteristics, corporate governance and environmental disclosure. The study used secondary source of data. The used of secondary data is justified because of its objectivity and quantitative nature of the study. The dependent variable of the study is the environmental disclosure was measured using disclosure index. The independent variable of the study is firm attributes and corporate governance

Table 1 Variable of the Study and their Measurements

\begin{tabular}{|l|l|}
\hline Variables & Measurements \\
\hline Dependent Variable & Disclosure indices \\
\hline Environmental Disclosure & Proportion of foreign directors on the board \\
\hline Independent Variables & Number of directors with relevant qualification in the field of business \\
\hline $\begin{array}{l}\text { Educational background of the directors } \\
\text { director }\end{array}$ & $\begin{array}{l}\text { Proportion of director that seat on the board of other companies to total } \\
\text { directors }\end{array}$ \\
\hline Director with dual directorship & Proportion of independent directors to total directors \\
\hline Independent directors & Number of years since the firm foundation \\
\hline Control Variables & Log of total assets \\
\hline Firm age & \\
\hline Firm size &
\end{tabular}

Source: Authors computation

\subsection{Model Specification}

For the purpose of this research work, the following model was made available; ENVDit $=\beta_{\mathrm{o}}+\beta_{1}$ FORGit $+\beta_{2}$ EGBDit $+\beta_{3}$ DUDSit $+\beta_{4}$ INPDit $+\beta_{5}$ FRMAit $+\beta_{6}$ FRMSit + eit

Where;

ENVD= environmental disclosure

$$
\beta_{0}=\text { intercept }
$$

$\beta_{1}-\beta_{6}=$ coefficient of the independent variables

$\mathrm{FORG}=$ foreign director

$\mathrm{EGBD}=$ educational background of directors

DUDS $=$ directors with dual membership

INPD $=$ Independent Directors on the board

FRMA = firm age

FRMS $=$ firm size

$\mathrm{e}=$ error term 


\subsection{Results and Discussions}

TABLE 2 FIXED EFFECT REGRESSION RESULT

\begin{tabular}{|l|l|l|l|l|}
\hline Vaiables & Coefficient & Standard Error & t-value & P-value \\
\hline INPD & 0.4546343 & 0.2198461 & 2.07 & 0.042 \\
\hline FORG & 0.1861968 & 0.1342064 & 1.39 & 0.169 \\
\hline DUDS & 0.1655113 & 0.1132774 & 1.46 & 0.148 \\
\hline EDBG & 0.0699051 & 0.0454975 & 1.57 & 0.129 \\
\hline FRMA & 0.0137161 & 0.0044708 & 3.07 & 0.003 \\
\hline FRMS & 0.0065995 & 0.131006 & 0.50 & 0.616 \\
\hline CONS & -0.662215 & 0.3378931 & -1.95 & 0.054 \\
\hline R-SQUARE & WITHIN & & & 0.3968 \\
& BETWEEN & & & 0.1488 \\
& OVERALL & & & 0.1518 \\
\hline
\end{tabular}

Source: Authors' computation using stata 11.

From the table above which present the fixed effect regression result between corporate governance and environmental disclosure. The overall $\mathrm{R}^{2}$ of 0.15 indicates that about $15 \%$ of variation in the dependent variable is been explained by the variation in the independent variables (INPD, FORG, DUDS \& EDBG). Independent director is found to have positiv significant impact on the environmental disclosure. This finding agrees with Fortunella and Hadipajitno (2015) and dispute with the findings of Emmanuel et al. (2018). Foreign directors, directors with dual membership and educational background of directors have positive insignificant impact on environmental disclosure. This implies that three proxies of corporate have nothing to do with environmental disclosure. the control variables firm age has positive impact on environmental disclosure that is to say as firm grow old, it also increases disclosure. Lastly firm size has positive insignificant impact on environmental disclosure.

\subsection{Conclusion}

From the result and discussion, the study concludes that an independent director has positive significant impact on the environmental disclosure of listed manufacturing companies in Nigeria. However, proportion of foreign directors, educational background of the director and proportion of independent directors have positive insignificant impact on environmental disclosure of listed manufacturing companies in Nigeria.

\subsection{Recommendation}

The study recommended based on the findings of the study that companies should have more independent directors on their board as their decisions will always favor firm's existence. Moreso, companies should have environmental committee, that will help them identify the need of their host environment

\section{References}

Aburaya, R. (2012). The Relationship Corporate Governance and Environmental Disclosure: UK Evidence. Durban Thesis, Durban University.avalable at Durban E-thesis online. 1-475.

Akanno, S.A., Che, F., Radda, A. \& Uzodinma. (2015). Pattern of CorporateSocial and Environmental Disclosure in nigeria. international journal of business and financial management research, 3, 71-82.

Akbas, H.E. (2016). The relationship between board characteristics and environmental Disclosure: evidence from Turkish listed companies. South East Europian journal of economics and business, 11(2): 7-19.

Ajibolade, S.O. \& Uwuigbe, U. (2013). Effect of Corporate Governance on Corporate Social and

Environmental Disclosure among Listed Firms in Nigeria. European Journal of Business and Social Sciences, 2(5):76-92.

Ahmad, A.C. \& Noskhare, O. (2015). Directors Culture and Environmental Disclosure Practices f Companies in Malaysia. International Journal of Business and Technopreneurship, 5(1):99-114.

Aburaya, R. (2017). Corporate Environmental disclosure and Corporate Governance. A Critical Review. Journal of Empirical Research in Accounting and Auditing, 4(1): 25-53.

Aliyu, U.S. (2019). Board Characteristics and Corporate Environmental Reporting in Nigeria.Asian Journal of Accounting Research, 4(1): 2-17

Dibia, N.O. \&Onwuchekwu, J.O. (2015).Determinant of Environmental Disclosure in Nigeria. A Case Study of Oil and Gas Companies. International journal of Finance and Accounting, 4(3):145-152.

Elsakit, O.M. and Worthington, A.C. (2014). The impact of corporate characteristics and Corporate governance on corporate social and environmental disclosure: A literatureReview. International journal of business and management, $9(9)$

Emmanuel, O., Uwuigbe, U., Teddy, O., Tolutope, I. \& Eyitomi, G.A. (2018). Corporate Diversity and Corporate 
Social Environmental Disclosure of Listed Manufacturing Companies in Nigeria. Problems and Prospectives in Managements, 16(3):229-244.

Gatimbu K.K. and Wabwire, J.M. (2016). Effect of Corporate Environmental Disclosure on Financial Performance of Firms listed at Nairobi stock exchange, kenya. International journal of sustainability magement and information technology, 1-6.

Hartikayarti, H.N., Trisyardi, M.R. and Saptano, B. (2016). Effect of corporate characteristics on Environmental disclosure. IJABER, 14(10): 6111-6134.

Masud, A.K., Nurunnabi, M. \& Bae, S.M. (2018). Asian Journal of Sustainable and Social Responsibility, 3(3):126.

Melina, R. (2012). Environmental disclosure makes companies look greener. $\mathrm{http} / / \mathrm{www}$.livescience.com/corporate environmental repuation.html.

Mohamad,T., Olfa, B.J. \& Fauzi, J. (2014). Corporate Social Disclosure: Explanatory Theories Conceptual Framework. International Journal of Academic Research, 3(1): 208-225.

Nor, N., Bahari, A., Adnan, N., Kamal, S. and Ali I (2015). The effect of Environmental disclosure on financial perfomance in Malaysia. $7^{\text {th }}$ International Economics \&Business Management conference.117-126.

Oba, V.C. and Fodio, M.I. (2012). Board characteristics and the quality of environmental Reporting in Nigeria. Journal of accounting and management, 2(2): 33-48.

Odoemelam, N. \& Okafor, R.G. (2018). The Influence of Corporate Governance on Environmental Disclosure of Listed Non Financial Firms in Nigeria. Indonesian Journal of Sustainability Accounting and Management, 2(1):25-9

Ofoegbu, N.G. \& Odoemelam, N. (2018). Corporate Board Characteristics and Environmental Disclosure Quality: a Comparative Analysis of Traditional and Integral Reporting Evidence. www.preprint.org.

Rabi, A.M. (2019). Board Characteristics and Environmental Disclosure: Evidece from Jordan International Journal of Business and Management, 14(2):57-65.

Setyawan, H. and Kamilla, P. (2015). Impact of corporate governance on corporate Environmental disclosure: Indonesian evidence. International conference on trends in Economics, humanities and management. 13-18

Soliman, M.M. (2013). Firm characteristics and the extent of voluntary disclosure: The case Of Egypt. Research journal of finance and accounting, 4(17): 71-80.

Triresani, T. \& Djajadikerta, H.G. (2016). Corporate Governance and Environmental Disclosure in the Indonesian Mining Industry. Austrilasian Accounting, Business \& Finance Journal, 10(1): 17-28.

Uddin, A.and Safiuddin,M. (2015). Narrative reporting disclosures. A case of selected companies in Dhaka stock exchange. The cost and management, 43(5): 41-50. 